\title{
Epidemiology of Melanoma in the South of Brazil: study of a city in the Vale do Itajaí from 1999 to $2013^{*}$
}

\author{
Adma Silva de Lima ${ }^{1}$ \\ Karla Patricia Casemiro ${ }^{3}$
}

\author{
Carlos Efrain Stein ${ }^{2}$ \\ Rodrigo Kraft Rovere ${ }^{4}$
}

\begin{abstract}
BACKGROUND: Cutaneous melanoma is a highly aggressive malignancy with increasing incidence worldwide. The southern Brazilian state of Santa Catarina has one of the highest incidence rates of melanoma in the country.

OвJестіvE: To evaluate the epidemiological profile of melanoma patients in a southern city of Brazil.

METHODS: a cross-sectional retrospective study was conducted, aiming to detect the clinical and histopathological characteristics of cutaneous melanoma diagnosed in the city of Brusque - SC, between 1999 and 2013.

RESULTS: A total of 213 cases in 212 individuals were studied. More than $50 \%$ of the patients were females $(\mathrm{p}<0.05)$. The trunk was the most commonly affected site $(p<0.05)$, followed by the upper limbs. Nodular and superficial spreading melanomas were the most commonly detected in histological analyses. They did not differ statistically in frequency, but were more prevalent than other histopathological subtypes $(\mathrm{p}<0.05)$. There was no statistically significant difference between invasive and noninvasive melanomas $(p=0.2441)$. Among the invasive melanomas, those with Breslow thicknesses $<1 \mathrm{~mm}$ and between $1-2 \mathrm{~mm}$ were more prevalent $(\mathrm{p}<0.05)$.

CONCLUSIONS: In this study we found a higher frequency of melanomas in female patients and patients aged over 51 . The trunk was the most commonly affected site. Nodular and superficial spreading melanomas prevailed. Among invasive melanomas, those with Breslow thicknesses $<2 \mathrm{~mm}$ were the most frequent. This paper highlights the epidemiological profile of melanoma patients in the city and may help to identify and aid in the follow-up of those who are most likely to present the disease.
\end{abstract}

Keywords: Epidemiology; Melanoma; Neoplasms; Nevi and melanomas

\section{INTRODUCTION}

Cutaneous melanoma (CM) is a highly aggressive malignancy, originating from melanocytes, whose incidence is increasing worldwide, especially among the Caucasian population. ${ }^{1-13}$ Australia and New Zealand have the highest incidence rates, with approximately 40-60 cases/100.000 inhabitants. ${ }^{9,14}$ In Brazil, according to the National Cancer Institute (INCA), estimated incidence rates for 2010 varied between 2.92-3.72/100.000 inhabitants, differing slightly between men and women. The highest incidence rates are found in the south of Brazil. ${ }^{9,10,14}$

Received on 22.08.13.

Approved by the Advisory Board and accepted for publication on 16.03.2014

* *Work performed at the Private Clinic - Brusque (SC), Brazil.

Financial support: none.

Conflict of interests: none.

Private Clinic - Brusque (SC), Brazil

Fundação Regional de Blumenau (FURB) - Blumenau (SC), Brazil.

Vitalab - Brusque (SC), Brazil.

Hospital Santo Antonio - Blumenau (SC), Brazil.
Brazil is a continentally large country with diverse ethnic characteristics, which vary depending on the region. ${ }^{10,15}$ Southern Brazil was largely colonized by European immigrants during the $19^{\text {th }}$ and $20^{\text {th }}$ centuries ${ }^{10}$. According to previous studies, Santa Catarina is the state with the highest melanoma rates in the country, followed by Rio Grande do Sul. ${ }^{9,15,16}$

In a study carried out in the city of Blumenau Santa Catarina, Brazil, Nasser found incidence rates of approximately 22.4/100.000 inhabitants, which are much higher than mean Brazilian figures. ${ }^{16}$ The area around Blumenau was largely colonized by European 
immigrants, especially Germans. The city of Brusque is located in southern Brazil, in the northwest of Santa Catarina, in the Itajai River Valley, approximately 40 kilometers from Blumenau. ${ }^{17}$ According to the 2010 census from the Brazilian Institute of Geography and Statistics (IBGE), its population is $105.502,{ }^{18}$ most of which is made up of Italian, German and Polish descendants.

We conducted this study in order to verify the clinical and epidemiological profile of melanoma patients in the city of Brusque. Further understanding of the epidemiological features of these patients may help to improve treatment of patients from this region and enhance precocious detection. To the best of our knowledge, this is the first study of its kind to be conducted in Brusque.

\section{MATERIALS AND METHODS}

We performed an observational descriptive retrospective study based on data collected from patients diagnosed with melanoma in Brusque - Santa Catarina - Brazil, between 1999 and 2013. One of the authors revised all the histopathological reports from January 1999 to February 2013. Clinical data were collected, including gender, age and localization of the primary lesion. Histopathological data, such as melanoma subtype, Breslow index and Clark index were also assessed.

Inclusion criteria were patients with $\mathrm{CM}$ diagnosed clinically and histopatologically during the period described above. Patients with extra-cutaneous primary disease were also included (1 case). Doubtful cases or cases in which some of the aforementioned data could not be assessed, were excluded from the study.

Data were analyzed using Epi Info V7 2013 software in order to compare the frequencies of the variables in each distribution, using the Goodness of Fit Chi-square test. We also estimated the frequency (proportions) with a 95\% Confidence interval (CI). The results are summarized below.

\section{RESULTS}

A total of 213 lesions were detected in 212 patients.

The majority of patients were females $-56.6 \%$. Males represented $42.92 \%$ of the total amount of patients and in one case $(0.4 \%)$, the gender was not specified. Females were statistically more frequently affected by melanoma, compared with males $(p<0.05)$ - Table 1

Most patients were aged 51 or over $(50.47 \%)$, followed by $31-50$ years (34.91\%). Only a few patients were under $30(11.32 \%)$. These age range differences were statistically significant, as patients over 51 were more frequently affected by melanoma than the other age groups $(p<0.05)$ - Table 1.

The trunk was the most common site of the primary lesion $(30.19 \%)$, followed by the upper limbs $(19.34 \%)$, head and neck (18.87\%) and lower limbs $(13.21 \%)$ - Table 1. Two patients presented with mucosal melanomas and one patient presented with a primary sigmoid melanoma. In approximately $17 \%$ of the cases, the site of the primary lesion was not specified. The trunk was the most commonly affected site and it was statistically significant $(p<0.05)$.

The histopathological analysis revealed that most of the diagnosed lesions were invasive melanomas (54\%) while in situ melanomas occurred in $46 \%$ of the cases. This difference was not statistically significant $(\mathrm{P}=0.2441)$. Among invasive melanomas, the most frequently found Breslow thicknesses were under $1 \mathrm{~mm}$ and between $1-2 \mathrm{~mm}$. These two groups did not differ in terms of frequency but were more common than the others $(p<0.05)$.

Nodular melanoma was found in $22.54 \%$ of the patients, followed by superficial spreading melanoma, present in $19.25 \%$. Although the frequencies did not differ between these two histological types, they were more common in comparison to the others $(\mathrm{p}<0.05)$.

\section{DISCUSSION}

United States statistics reveal that $20 \%$ of the population will develop some form of skin cancer during their lifetime. ${ }^{2} \mathrm{MM}$ is only the third most common skin cancer, alongside basocelular carcinoma and squamous cell carcinoma, but it is far more aggressive than the others.

Brazil is a country of continental dimensions with a complex ethnic background, exhibiting many differences. Hence, epidemiological studies conducted in the country show discrepant incidence rates and epidemiological characteristics, depending on the region in which they are performed. ${ }^{6,8,9,11,13,14,15,16,19-22}$ For instance, in the south and southwest of Brazil, melanoma patients are usually characterized as low phototype individuals (I-III) and the most commonly found histopathological subtype is superficial spreading melanoma. However, in the north of Brazil, a previous study reported that the predominant subtype is acral lentiginous melanoma and most patients are non-white. ${ }^{20}$ Further, there is a predominance of studies on the south of the country, while studies on the north and northeast are scarce.

For historical reasons, southern Brazil was colonized mostly by Europeans during several immigrant waves throughout the last 150 years, which is reflected in the fact that the population is composed mainly of fair-skinned individuals. ${ }^{9}$ Since these indi- 
TABLE 1: Epidemiological profile and statistical analyses

\begin{tabular}{|c|c|c|c|c|}
\hline Characteristics & $\begin{array}{l}\text { Patients } \\
(\mathrm{n}=212)\end{array}$ & $(\%)$ & $(95 \%)$ & $\mathbf{P}$ \\
\hline \multicolumn{5}{|l|}{ Sex } \\
\hline Female & 120 & $(56.6 \%)$ & $(49.93 \%-63.28 \%)$ & 0.0459 \\
\hline Male & 91 & $(42.92 \%)$ & $(36.26 \%-49.59 \%)$ & \\
\hline Unclassified & 1 & $(0.47 \%)$ & $(0 \%-\quad 1.39 \%)$ & \\
\hline \multicolumn{5}{|l|}{ Localization } \\
\hline Head and neck & 40 & $(18.87 \%)$ & $(13.6 \%-\quad 24.13 \%)$ & 0.0017 \\
\hline Upper Limbs & 41 & $(19.34 \%)$ & $(14.02 \%-24.66 \%)$ & \\
\hline Lower Limbs & 28 & $(13.21 \%)$ & $(8.65 \%-\quad 17.77 \%)$ & \\
\hline Trunk & 64 & $(30.19 \%)$ & $(24.01 \%-36.37 \%)$ & \\
\hline Mucosa & 2 & $(0.94 \%)$ & $(0 \%-\quad 2.24 \%)$ & \\
\hline Sigmoid & 1 & $(0.47 \%)$ & $(0 \%-\quad 1.39 \%)$ & \\
\hline Unknown & 36 & $(16.98 \%)$ & $(11.93 \%-22.04 \%)$ & \\
\hline \multicolumn{5}{|l|}{ Age (years) } \\
\hline $\mathrm{i} \leq 30$ & 24 & $(11.32 \%)$ & $(7.06 \%-15.59 \%)$ & $<0.001$ \\
\hline $31 \leq \mathrm{i} \leq 50$ & 74 & $(34.91 \%)$ & $(28.49 \%-41.32 \%)$ & \\
\hline $\mathrm{i} \geq 51$ & 107 & $(50.47 \%)$ & $(43.74 \%-57.2 \%)$ & \\
\hline Unknown & 7 & $(3.3 \%)$ & $(0.9 \%-\quad 5.71 \%)$ & \\
\hline \multicolumn{5}{|l|}{ Histological subtype } \\
\hline "IN SITU" & 98 & $(46.01 \%)$ & $(39.32 \%-52.7 \%)$ & $<0.001$ \\
\hline Nodular & 48 & $(22.54 \%)$ & $(16.92 \%-28.15 \%)$ & \\
\hline Superficial Spreading & 41 & $(19.25 \%)$ & $(13.95 \%-24.54 \%)$ & \\
\hline Spitzoid & 1 & $(0.47 \%)$ & $(0 \%-\quad 1.39 \%)$ & \\
\hline Fusocelular & 1 & $(0.47 \%)$ & $1.39 \%)$ & \\
\hline Microinvasor & 2 & $(0.94 \%)$ & $2.23 \%)$ & \\
\hline Acral & 1 & $(0.47 \%)$ & $1.39 \%)$ & \\
\hline Unclassified & 21 & $(9.86 \%)$ & $(5.86 \%-$ & \\
\hline "INVASIVE" & 115 & $(53.99 \%)^{*}$ & $(47.3 \%-60.68 \%)$ & $<0.001$ \\
\hline "IN SITU" & 98 & $(46.23 \%)$ & $(39.52 \%-52.94 \%)$ & \\
\hline$\leq 1 \mathrm{~mm}$ & 38 & $(17.92 \%)$ & $(12.76 \%-23.09 \%)$ & \\
\hline $1.1 \leq \mathrm{x} \leq 2 \mathrm{~mm}$ & 25 & $(11.79 \%)$ & $(7.45 \%-16.13 \%)$ & \\
\hline $2.1 \leq x \leq 3 \mathrm{~mm}$ & 13 & $(6.13 \%)$ & $(2.9 \%-9.36 \%)$ & \\
\hline $3.1 \leq \mathrm{x} \leq 4 \mathrm{~mm}$ & 12 & $(5.66 \%)$ & $(2.55 \%-8.77 \%)$ & \\
\hline $4.1 \leq x \leq 5 \mathrm{~mm}$ & 5 & $(2.36 \%)$ & $(0.32 \%-4.4 \%)$ & \\
\hline$\geq 5.1 \mathrm{~mm}$ & 15 & $(7.08 \%)$ & $(3.62 \%-10.53 \%)$ & \\
\hline Unclassified & 6 & $(2.83 \%)$ & $(0.6 \%-5.06 \%)$ & \\
\hline
\end{tabular}

I - CI - 95\% confidence interval (estimated proportion) II - P: P-value for chi-square test. If P $<0.05$ then there are significant differences between proportions within the distribution.

* One of the invasive melanomas was located in the sigmoid and its Breslow index was not computed

viduals are already known to be at high risk of $\mathrm{CM}$ development, it is expected that this region should have higher melanoma rates..$^{23}$ The south of Brazil also has similar latitudes to Australia, the country with the highest melanoma rates in the world.

Many studies of CM in the Brazilian population have been conducted in the southern states. Numerous studies, including the present study, have been performed in Santa Catarina, showing similar histopatho- logical and epidemiological features, but differing slightly as regards the predominant affected body site. 9,15,21,22 Further, they do not all discuss the same stage of disease. Konrad et al. ${ }^{22}$ detected mainly in situ melanomas, while Battisti et al. ${ }^{21}$ discovered that most of their studied lesions were already invasive at the diagnosis. In the present study, there was no significant difference between invasive and non-invasive melanomas. Even among invasive melanomas, those 
with Breslow thicknesses under $2 \mathrm{~mm}$ prevailed. Nevertheless, it is interesting to note that during the last four years (2009-2013), most of the lesions diagnosed were in situ melanomas (52\% in situ as opposed to $48 \%$ invasive melanomas). This data may reflect the fact that, in recent years, there has been a rise in in situ melanoma detection, due mainly to more intensive screening and new technologies such as dermoscopy, digital dermoscopy and reflectance confocal microscopy. Precocious diagnosis is fundamental in melanoma patients care. Given the development of new medical devices that aid in early diagnosis, and since physicians as well as the general population are more aware of the disease's features, an increase in the detection of in situ melanomas might occur in the future. Although recently-launched drugs for metastatic melanoma have helped to increase survival rates among patients with advanced disease, early detection remains crucial in improving prognosis. ${ }^{24,25}$

In 2003, Gilles et al., representing the Brazilian Melanoma Group (GBM), published a consensus regarding pathology reports on cutaneous melanoma in Brazil. ${ }^{10,26}$ Since then, efforts have been made to standardize pathological analyses in Brazil. As the present study began before the consensus, some lesions were not classified in accordance with it; nevertheless, in recent years, histopathological reports have taken the form suggested by the consensus.

Bakos et al. have outlined a model to detect patients at increased risk of melanoma. ${ }^{27}$ Associated factors are light hair, eye and skin color, as well as freckles and sunburn. ${ }^{7,12}$ Previous papers have also demonstrated the effect of European ancestry on CM risk, finding a positive correlation. ${ }^{6,10,23}$ Mutations in CDKN2A, CDK $4{ }^{27}$ and $\mathrm{XPC}^{23}$ genes may be responsible for this additional risk. ${ }^{27}$

Nasser conducted a large study in the city of Blumenau, revealing far higher melanoma incidence rates than those found in the Brazilian population in general. ${ }^{16}$ The population of the city of Brusque is geographically close and ethnically similar to that of Blumenau, so it is subjected to the same risk factors. In accordance with Nasser's study, ours also showed higher incidence rates in patients aged over 50, in addition to a predominance among females; and found that the trunk was the most affected site.

\section{CONCLUSION}

This is an epidemiological study of the melanoma profile of patients in the city of Brusque. We found that melanomas were more frequent in females, in patients aged over 51, while the most commonly affected body site was the trunk. There was no difference between the superficial spreading and nodular melanoma subtypes, but they were more frequent than the others. Further, there was no statistically significant difference between invasive and in situ melanomas. Nevertheless, with respect to invasive melanomas, most had Breslow thicknesses of between under $1 \mathrm{~mm}$ and $1-2 \mathrm{~mm}$. 


\section{REFERENCES}

1. Brehmer F, Ulrich M, Haenssle HA. Strategies for early recognition of cutaneous melanoma - presente and future. Dermatol Pract Concept. 2012;2:203a06.

2. Gontijo GT, Pugliesi MCC, Araujo FM. Fotoproteção. Surg Cosmet Dermatol. 2009;1:186-92.

3. Tsao H, Atkins MB, Sober AJ. Management of cutaneous melanoma. N Engl J Med. 2004;351:998-1012.

4. Goodson AG, Grossman D. Strategies for early melanoma detection: approaches to the patient with nevi. J Am Acad Dermatol. 2009;60:719-35.

5. Eide MJ, Weinstock MA, Clark MA. The association of Physician Specialty Density and Melanoma Prognosis in the United States, 1988-1993. J Am Acad Dermatol. 2009;60:51-8.

6. Luiz OC, Gianini RJ, Gonçalves FT, Francisco G, Festa-Neto C, Sanches JA, et al. Ethnicity and Cutaneous Melanoma in the City of Sao Paulo, Brazil: A Case Control Study. PLoS One. 2012;7:e36348.

7. Bakos L, Mastroeni S, Bonamigo RR, Melchi F, Pasquini P, Fortes C. A melanoma risk score in a Brazilian population. An Bras Dermatol. 2013;88:226-32.

8. Ashton-Prolla P, Bakos L, Junqueira G Jr, Giugliani R, Azevedo SJ, Hogg D. Clinical and Molecular Characterization of Patients at Risk for Hereditary Melanoma in Southern Brazil. J Invest Dermatol. 2008;128:421-5.

9. Moreno M, Schmitt RL, Lang MG, Gheno V. Epidemiological Profile of Patients with Cutaneous Melanoma in a Region of Southern Brazil. J Skin Cancer 2012;2012:917346.

10. Bakos L, Masiero NC, Bakos RM, Burttet RM, Wagner MB, Benzano D. European ancestry and cutaneous melanoma in Southern Brazil. J Eur Acad Dermatol Venereol. 2009;23:304-7.

11. Borges SZ, Bakos L, Cartell A, Wagner M, Agostini A, Lersch E. Distribution of clinical-pathological types of cutaneous melanomas and mortality rate in the region of Passo Fundo, RS, Brazil. Int J Dermatol. 2007;46:679-86

12. Bakos L, Wagner M, Bakos RM, Leite CS, Sperhacke CL, Dzekaniak KS, et al. Sunburn, sunscreens, and phenotypes: some risk factors for cutaneous melanoma in southern Brazil. Int J Dermatol. 2002;41:557-62.

13. Ferrari Júnior NM, Muller $H$, Ribeiro $M$, Maia $M$, Sanches Júnior JA. Cutaneous melanoma: descriptive epidemiological study. Sao Paulo Med J. 2008;126:41-7.

14. Brandão FV, Pereira AF, Gontijo B, Bittencourt FV. Epidemiological aspects of melanoma at a university hospital dermatology center over a period of 20 years. An Bras Dermatol. 2013:88:344-53.

15. Bonfá R, Bonamigo RR, Bonfá R, Duro KM, Furian RD, Zelmanowicz Ade M. Early diagnosis of cutaneous melanoma: an observation in southern Brazil. An Bras Dermatol. 2011;86:215-21

16. Nasser N. Cutaneous melanoma: a 30-year-long epidemiological study conducted in a city in southern Brazil, from 1980-2009. An Bras Dermatol. 2011; 86:932-41.

17. Brusque.sc.gov [Internet].Prefeitura Municipal de Brusque. Perfil da Cidade [cited Jul 27]. Available from: http://www.brusque.sc.gov.br/web/perfil.php.

18. Ibge.gov [Internet]. Instituto Brasileiro de Geografia e Estatísticas. Santa Catarina Brusque: síntese das informações [acesso 27 Jul 2013]. Disponível em http://www.ibge.gov.br/cidadesat/xtras/temas.php?codmun=420290\&idte$\mathrm{ma}=16 \&$ search $=$ santa-catarina $\mid$ brusque $\mid$ sintese-das-informacoes.

19. Maia M, Russo C, Santos ABO, Ferrari N, Ribeiro MCSA. Reflections regarding The Epidemiology of Cutaneous Melanoma in Brazil. An Bras Dermatol. 2002;77:163-70.
20. Chiba FB, Schettini AP, Delfino AC, Chirano CA, Damasceno S de A. Clinical and epidemiological profile of cutaneous malignant melanomas in two referral institutions in the city of Manaus, Brazil. An Bras Dermatol. 2011;86:1239-41.

21. Battisti R, Nunes DH, Weber AL, Schweitzer LC, Sgrott I. Evaluation of the epidemiological profile and the mortality rate of the patients with primary cutaneous melanoma in Florianopolis - SC, Brazil. An Bras Dermatol. 2009;84:335-42.

22. Konrad P, Fabris MR, Melao S, Blanco FLO. Histopathological and epidemiological profile of cases of primary cutaneous melanoma diagnosed in Criciuma-SC between 2005 and 2007. An Bras Dermatol. 2011;86:457-61.

23. Gonçalves FT, Francisco G, de Souza SP, Luiz OC, Festa-Neto C, Sanches JA, et al. European ancestry and polymorphisms in DNA repair genes modify the risk of melanoma: a case-control study in a high UV index region in Brazil. J Dermatol Sci. 2011:64:59-66

24. Wolchok JD, Kluger H, Callahan MK, Postow MA, Rizvi NA, Lesokhin AM, et al. Nivolumab plus ipilimumab in advanced melanoma. N Engl J Med. 2013;369:122-33.

25. Chapman PB, Hauschild A, Robert C, Haanen JB, Ascierto P, Larkin J, et al. Improved survival with vemurafenib in melanoma with BRAF V600E mutation. N Engl J Med. 2011;364:2507-16

26. Landaman G, Muller H, Neto JM, Maceira JMP, Marques M, Costa MB et al Pathology report consensus for cutaneous melanoma. Brazilian Multicentric and Multidisciplinary Group for the Study of Melanoma (GBM). Acta Oncol Bras. 2003:23:504-10

27. Bakos RM, Besch R, Zoratto GG, Godinho JM, Mazzotti NG, Ruzicka T, et al. The CDKN2A p.A148T variant is associated with cutaneous melanoma in Southern Brazil. Exp Dermatol. 2011;20:890-3.

How to cite this article: Lima AS, Stein CE, Casemiro KP, Rovere RK. Epidemiology of Melanoma in the South of Brazil: study in a city of Vale do Itajaí from 1999 to 2013. An Bras Dermatol. 2015;90(2):185-9. 